\title{
DigitalCommons@NYLS
}

Books

Faculty Scholarship

2016

\section{The U.S.-Taiwan-China Relationship in International Law and \\ Policy (2016)}

Lung-chu Chen

New York Law School

Follow this and additional works at: https://digitalcommons.nyls.edu/fac_books

\section{Recommended Citation}

Chen, Lung-chu, "The U.S.-Taiwan-China Relationship in International Law and Policy (2016)" (2016).

Books. 110.

https://digitalcommons.nyls.edu/fac_books/110

This Article is brought to you for free and open access by the Faculty Scholarship at DigitalCommons@NYLS. It has been accepted for inclusion in Books by an authorized administrator of DigitalCommons@NYLS. 


\section{The U.S.-Taiwan-China Relationship in International Law and Policy}

Lung-chu Chen

\section{OXFORD}




\section{OXFORD}

UNIVERSITY DRHSS

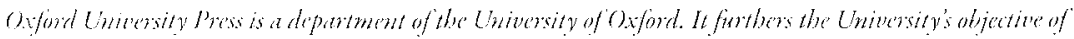

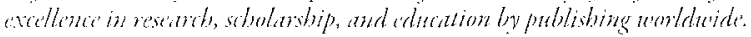

()xtord New York

Auckland Cape Lown Dareshalan Hong Kong Karachi Kinalia Lumpur Madrid Melbourne Mexico(jey Nambi New Delhi Shanghai Iaipej Toronto

With offices in

Argentina Austria Brarit Chile Cach Republic Hance Cieced Cuatemala Hungary ltaly Japan Polund Portugal Singapore Southkorea Switserland Thailand Ciukcy Ukring Victman

Oxford is a registered tradenate of Oxford University Press in the UK and certain other couneries.

Published in the United Suates of Ancrica by

() ford Universicy Press

19) Mirdison Avenuc, Ncw York, NY roon6

(c) ()xford University Press 2016

Al rights reserved. No part of this publication nay be reproduced, seored in a recrieval sysem, of transmitcd, in any form or by any means, without the pror permission in writing of

()xford University Press, or as expressly permited by law, by liconse, or under terms agreced with the appropriate reproduction rights organization. Inquiries concening reproduction outside the scope of the above should be sent to the Righes 1) epartment, () ford University Press, at dhe address above.

You muse not circulate this work in any other form

and you tumst impose this same condition on any acyuirer.

\section{Library of Congress (ataloging-ju-Publication 1)aca}

Names: Chen, loung-chu, author.

Titke: The US.-Iaiwan-China relationship in intemational law and policy/ Iung-chu Chen.

1)excription: New York : ()xford University Press, $20 \mathrm{~m}$. Inchdes bibliographical references and index.

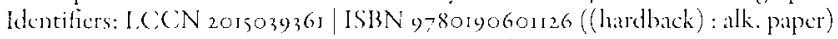

Subjects: I.CSH: 'Iawan-.. International status. | lawan-Relations-China |

lawan-Foreign relarions-United States. | Tawan--Politics and governnent-1945-

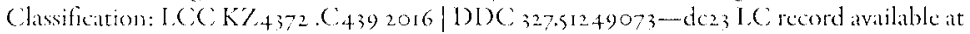
hetp://kcn.loc:gov/2015039361

$98765+321$

Printed in the United States of Anerica on acid-free piper

\section{Note to Readers}

This publication is designed to provide accurate and authoritative information in regard eo the subject matter covered. It is based upon sources believed to be accurate and reliable and is intended to be current as of the time it was writch. It is sold with the anderstanding that the publisher is not engaged in rendering legal, aceounting, or other professional services. If legat advice on other expert assistance is required, the services of a competent professional person should be sought. Also, to confirm rhat the information has not been affected or changed by recent developments, traditional legal rescarch techniques should be used, including checking primary sources where appropriate.

(Based ow the Dethetation of Principles jombly atopted by a Committe of the

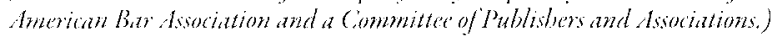

\section{You may order this or any other Oxford University Press publication by visiting the 0xford University Press website at www.oup.com}




\section{Contents}

About the Author xv

Preface xix

Introduction Xxy

PAR'I ONE | HISTORICAL AND CONTEMPORARY FAC'S

1. Historical Bateground 3

I. 'laiwan's Geographic Importance?

II. From Ancient Settlers to World War Il ;

A. Taiwan's First Inhabitants 6

B. Historical Connections between 'lawan and China ?

C. Western Colonization 8

D. Qing Rule of Taiwan (1683 t0 1895) 9

E. The Mudan Incident of 187110

F. Japanese Colonization (1895 to 1945) in

III. Thiwan after World War II I3

A. The Nationalist Chinese Military (Ocupation (1945 to 1949) 13

B. The Nationalist Chinese in Fxile (1949 to 1987) 15

C. U.S. Policy toward Taiwan after World War II 16

D. The Taiwan Relations Act (1979) \& 8

Notes 20

2. Taiwan's Contemporay Landsape 23

I. From Authoritarian Rule to Democracy 24

A. Leec Teng-hui, "Mr. Democracy" 27

1I. Contemporary Politics in Taiwan 29
A. Chen Shui-bian 30
B. Ma Ying-jeou 32 
III. Taiwan's Economic Landscape 35

IV. Taiwan's Social and Cultural Landscape 38

V. 'Tawan's Diplomatic and Defense Landscape $4 \mathbf{I}$

A. Taiwan's Diplomatic Landscape 4 I

B. Taiwan's Defense Landscape 43

Notes 48

PART TWO | ARTICULATION OF GOALS ANDPOLICY CONSIDERATIONS 3. Charification of Common Interests 53

I. A Policy-Oriented Approach to International Law and World Affairs 53

A. Peace and Security 55

B. Universal Values of Freedom, Democracy, and Other Human Rights 57

C. Rule of Law 61

D. Economic Development 62

E. International Cooperation toward Minimum and Optimum World Order 63

II. 'Taiwan's International Legal Status Is a Matter of International Concern 64

1I1. Why Taiwan Matters 66

Notes 69

\section{The Evolution of Tatiwan Statehood 71}

I. Differing Viewpoints 72
A. Taiwan as a Part of China 73
B. Taiwan's Status Remains Undetermined since the San Francisco l'aace Treaty of 195180
C. Tawan Has De Facto But Not De Jure Independence 83

II. From Undetermined to Determined: 'The 'Theory of Taiwan's Evolution from a Militarily Occupied Territory to a State 83
A. Contemporary International Law on "Ferritorial Changes 84
B. Taiwan's Evolution to Statehood under International Law: Four Distinctive Stages 87

1. From I895 to 1945: Tawan Was a Territory and Colony of Japan 87

2. From 1945 to 1952: The ROC Undertook a Military Occupation on Behalf of the Allied Powers 88

3. From 1952 to 1987: The ROC Was a Regime in Exile that Engaged in an Illegal Military Occupation of Taiwan 88

4. From 1988 to the Present: Taiwan Achicved Effective Self-Determination of the People and Evolved into a Sovereign and Independent State 90

C. Effective Sclf-Determination or 


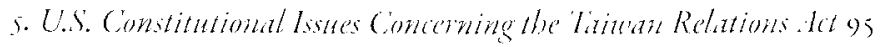

1. President Carter's Announcement os

A. History of the Negotiations over U.S.PRC 1)iplomatic Relations 100

[1. Inatment of the Taivan Relations Act 103

III. Congressional and Lxecutive Powers in Forcign Aftairs a

A. Theaty Making under the U.S. Constitution 113

B. 'Ihe TRA and the Threc Communiqués as

C. Conclusion: the l'RA ls the Law of the land 120

Notis 121

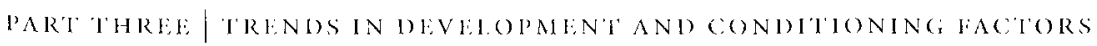
o. U.S.-Tituan Relations 127

I. U.S. - laiwan Relations before the Taivan Relations Act 128
A. U.S. Taivan Relations in the 19 . fos and 19505128
B. U.S.- Taiwan Relations in the 1960 and 1970 s 120

II. Application of the I'RA Since 1979131

A. Jimmy Carter (1979 to 1981) 132

B. Romald Reagan (1981 to 1989) $\mathrm{i}_{3+}$

C. (icorge H. W. Bush (1989 to 1993) 138

1). Bill Clinton (199; to 2001) I39

F. Gicorge W. Bush (2001 t0 2009) 145

1: Barack (Obama (2009 to the Present) 148

III. Interim Appratsal of Past Successes and Fatheses 150
A. Unofficial Relations 152
B. Preserving lawan's Distinctive Status 155
C. Taiwan's Democratic 1)evelopment 157
1). Fostering Taiwan's Participation in International Organizations 158

Notcs 160

\section{U.S.-China Relations 163}

I. U.S.-China Relations fiom 1945 to 197164

A. The Chinese Civil War 164

B. 'The Tivo Chinas and the United Nations 165

I1. Building the U.S.-China Relationship (1972) I68

A. President Nixon's Visit to China (1972) 168

B. Establishment of Liaison ()ffices (1973) 169

C. 'The Second Communique and Formal Recognition of the PRC (1978) $17 \mathbf{I}$

D. The Tawan Relations Act (1979) and the Third Communiqué (1982) 172

E. China Joins Multilateral Economic Institutions (1980 to 1991) 173 
F. The Tiananmen Square Massacre of Junc 4,1989174

(i. 'The Third Taiwan Strait Crisis (1995 to 1996) 175

H. Jiang Zemin's Visit to the United States (1997) 176

I. The Belgrade Embassy Bombing (1999) 178

J. China Joins the World Trade Organization (2001) 179

III. Recent liends in U.S.-China Relations i $8 \mathrm{I}$

A. The LP-3 Reconnaissance Plane Incident (2001) I 82

B. U.S.-China Relations after September If, 2001183

(. China and North Korca (2002 to the Present) 18.

1). 'The (ilobal Financial Crisis (2008 to 2009) 185

E. 'The United States' and China's "Core Interests" (2009 to the Present) 185 Notes 187

\section{S. Taiwan-Chima Relations isg}

I. Taiwan-China Rclations before 1949 191

A. Taiwan and China before 1895191

B. Taiwan under Japancse Colonial Rule (1895 to 1945) r92

C. 'The Chinese Civil War and the Birth of the PRC (1927 to 1949) 193

II. Taiwan-China Relations from 1945 to 1987194

A. Military Occupation of Taiwan by the KM' 194

B. KMT-CCP Hostilitics (1949 to 1987 ) 196

III. The Fra of Taiwanese Presidents (1988 to 2008) I99

A. Lec leng-hui (1988 to 2000) 199

B. Chen Shui-bian (2000 to 2008) 202

IV. The Fra of Ma Ying-jeou (2008 to the Present) 203

A. Ma's "Threc Noes" 203

B. Cross-Strait Economic Integration and 1)ependency 205

V. Conchusion: Security and Dignity for 'Iawan 207

Notes 209

PART HOUR | PROJECTIONS OR PROBABLE IUTURE DEVELOPMENTS و. A Developing U.S.-China Rivalyy? 213

I. Folving Chinese Perspectives 214

A. From Peaceful Cocxistence to Corc Interests 214

II. U.S.-China Economic Rivalry 218

A. China's Economic Expansion 219

B. Fxpanding Regional Influence 221

C. The Beijing Consensus 22.4 
1II. U.S.-China Strategic Rivalsy 226
A. China's Military Modemization 226
B. Regional Security Lssues 28
C. U.S. "Pivot" to the Asia Pacific 230

IV. The Future of U.S.-China Relations 232
A. International cooperation 232
13. Soft and Sinare Power 234
C. China as a Responsible Stakeholder 236
1). Chinais Long-'krm Intentions 237

Notes 241

10. Posible Future Detolopments. for Titiuan 245

I. The Context of Conditions 246
A. External Conditions 246
B. Taiwan's Internal Politics 248
C. The Predispositions of the People of Taiwan 250

II. Puture Projections 253
A. Taiwan as a l'art of China 254
B. The Finlandization of Tawwan 257
C. 'Taiwan as Asia's Switzerland 259
1). Taiwan as a Part of the United States 261
E. Maintaining the Status Quo 262

III. 'Taiwan as a Normalized Statc 264

Notes 268

PART FIVE | RECOMMENDATIONS OF POLICY ALTERNATIVES 11. Recommendations of Policy Altomatives 273

I. Enhance Taiwan-U.S. Trade through Bilateral Agreements and Thiwan's Participation and Mcmbership in the Trans-Pacific Partncrship 274
A. Bilateral Trade 275
B. Multilatcral Trade 278

II. Enhance Official and Nonofficial Contacts to Increasc Mutual Understanding at All Levels 280

III. Support Taiwan's Mcmbership or Meaningful Participation in Intcrnational Organizations, Both Governmental and Nongovernmental 283

IV. Support and Encourage Taiwan's Ongoing Efforts to Enhance the Actualization of the Universal Values of Democracy, Frecdom, and Other Human Rights 285 
V. Fortify Taiwan's Defense Capabilities through Arms Sales and Related Mcasures 287

A. Regional Military Imbalance 288

B. Arms Sales under the lawwan Relations Act (TRA) 289

VI. Reaffirm the Taiwan Relations Act 292

VII. Reappraise the U.S. Onc China Policy 294

VIII. Normalize Diplomatic Relations with Taiwan 297

IX. Support an Inernationally Supervised Plebiscite in Taivan to let the People of Taiwan Decide 'laiwan's Future 298

Notes 300

12. Let the People of Taine Inecide Titivan's Future 303

I. Plebiscites under International Law 305

A. Historical Development 305

B. Recent Examples 307

I. Québec, Canada 307

2. Kosovo 309

3. East Timor (Timor-Lcste) $3 \mathbf{r}$

4. South Sudan 312

5. The Falkland Islands $3 \mathrm{r}_{2}$

6. Scotland, United Kingdom 313

7. Crimea and Sevastopol, Ukrainc 314

II. Blucprint for a Taiwan Plebiscite 315

A. Initiating the Plebiscite 317

B. Establishing a Plebiscite Commission 320

I. Formulating the Questions 321

2. Eligilility for Voting 322

3. Public Information 323

4. Adopting the Outcomes 324

III. International Support for a Taiwan Plebiscite 325

IV. Conclusion: Let the Pcople of Taiwan Decide Taiwan's Future 327

Notes 330

SUGGESTED READINGS IN ENGILISH 331

SUGGLSTED READINGS IN CHINESE 34 I

I. Taiwan's International Legal Status in General 341

II. Differing Viewpoints Regarding Taiwan's International Legal Status 343

A. Taiwan's International Legal Status Was Determined a Long Time Ago; Tawan Belongs to China 343 
I. KMT's Vicwpoint $3+3$

2. CCP's Vicupoint $3+3$

3. 'lawan Is a Rencgade Province of China, Pending a Declatation of Independence $3+3$

B. Lawan's Internationad Lecgal Status Was Undetermined in the Past; It Remains Undetermined it 3

I. Taiwan's Sovereignty Bclongs to the Pcopke of lawan 3 t3

2. Taiwan's Sovercignty Belongs to the United States 344

3. ()ther 344

C. 'Taiwan's International I cegal Status Wis Undetermined in the Past, But Now Is 1)etermined: Tawan Is a Sovereign Independent State $34+$

I. 'The Iheory of Jawan's Lvolution as a State $34+4$

2. Taivan als a Newborn State its

3. Taiwan ls a Me lineto State, But Not Yet a le Jere State 345

III. Probable Future Developments for Taiwan 345

A. Normalized Statchood $3+5$

B. Neutrality of laivim $3+6$

C. Finlandization of Tawan 346

1). Taiwan as a l'art of the United States 34 ?

I:. Unification with China 347

1. Anned Liberation of liawan 347

2. Peaceful Liberation of laiwan $3+7$

3. One Country, 'Two Systems (Hong Kong Model) it8

4. A Circat China Structure $3+8$

5. KMI'-CCP Pcace Agrecment; Political Thansaction; Buy Taiwan with: Moncy $3+9$

F. Perpetuation of the Stanus Quo $3+9$

TEXT OF SELEOTED DOCUMLN'TS $35 \mathrm{I}$

'Iaiwan Relations Act (H.R. 2479; Public Law 96-89 Sth Congress) (Ixcerpt), Jantiary I, 1979351

Joint Communique of the United States of America and the People's Republic of China (The Shanghai Communiqué), February 27, 1972358

Joint Communique of the United States of America and the Pcople's Republic of China on the Establishment of 1)iplomatic Relations (The Second Communiqué), January 1, 1979 361

Joint Communiqué of the United States of America and the Pcople's Republic of China ("The Third (ommunique), August 17, 1982362

President Reagin's "Six Assurances" to Taiwan, July 1 4, 1982364 
President Reagan's Secret Memorandum on the 1982 Communiqué, August i7, 1982364

Democratic Progressive Party (DPP) r999 Resolution Regarding 'Taiwan's Future (Excerpt), December 2, 1999365

National People's Congress of the Pcople's Republic of China Anti-Secession Law, March I 4, 2005366

Peace Treaty between Japan and China (The Treaty of Shimonoscki) (Excerpt), April 17,1895368

The Cairo Declaration, November 27, 1943370

Proclamation Defining 'Terms for Japanese Surrender (The Potsdam Decharation), July 26, 1945371

Treaty of Peace with Japan (The San Francisco Peace Treaty) (Fxecrpt), Scptember 8, 1951 373

Tiraty of Peace between Japan and the Republic of China (The Treaty of Taipei) (Exccrpt), April 28, 1952377

Mutual Defense lieaty Between the United States and the Republic of China (Excerpt), December 2, 1954380

United Nations Gencral Asscmbly Resolution 2758 (XXVI), October 25, 1971382 Notes 382 